\title{
BIODIVERSITAS DAN POTENSI MIKROORGANISME PENTING DI BAWAH TEGAKAN JATI UNGGUL NUSANTARA (JUN) UMUR 5 TAHUN DI KEBUN PERCOBAAN COGREG BOGOR
}

\author{
Srikandi*, Lilis Sugiarti dan Mamay Maslahat \\ Fakultas MIPA UNB Bogor \\ Jl. K. H. Soleh Iskandar Km. 4, Cimanggu, Tanah Sareal - Bogor 16166 \\ Telp. 0252-8340217, 7535605 \\ *Email : sriuus@yahoo.co.id
}

\author{
ABSTRACT \\ Important Microorganisme and Potential Biodiversity Under The Superior \\ Teak Stands Nusantara (JUN) of 5 Years Old in \\ Experimental Garden, Cogreg, Bogor
}

\begin{abstract}
Biodiversita of mikoorganisme on the ground is a lot happen on the rhizosphere. Microorganisms can live in substrates released by the plant from the roots or in dead plants, it can also stimulate appearence of nutrients from the roots to produce compounds that accelerate growth. Biodiversity of rhizosphere bacteria isolated on Kings B medium and Nutrient Agar (NA) in the middle, front and rear land totaling 25 isolates with, different morphological colonies. Overall there were 22 morphological diversity of bacteria isolated on Kings medium $B$ and 3 bacteria on NA media. Each different colony of morphology could be for a different type. The number of colonies were isolated in Kings B medium reached the center of the $1.61 \times 108 \mathrm{cfu} / \mathrm{ml}$, the front as much as $7.87 \times 109 \mathrm{cfu} / \mathrm{ml}$ and the rear of the total population could not be calculated because each isolate population was > 250 colonies. Meanwhile, isolated on NA medium for the middle ground, and the front of the number of colonies isolated with NA media ineligible minimum and maximum standart calculation of bacteria which ranges between 25 - 250. For a population of bacteria in the back of soil his total of $2.23 \times 103 \mathrm{cfu} / \mathrm{ml}$. Mycorrhizae were found on the overall JUN stands dominated by Gigaspora type (65.3\%) followed by Glomus type $(28.6 \%)$ and Acaulospora (6.1\%). Two isolated namely isolates $1 A$ and $1 B$ showed the potential to produce a hormone IAA on the third day incubation period. Meanwhile, on the seventh day, all isolates were tested with reagents Salkowsi, not showad a positive reaction (red color does not appear). In the preliminary study, it was known that on the third day was the optimum day to produce the hormone IAA.
\end{abstract}

Keywords : Biodiversity, microorganisms, bacteria, morphology, hormone

\begin{abstract}
ABSTRAK
Biodiversita mikoorganisme pada tanah banyak terjadi di daerah rizosfer. Mikroorganisme dapat hidup dari substrat yang dikeluarkan oleh tanaman melalui akar ataupun tanaman yang mati, di samping itu dapat juga merangsang pengeluaran unsur hara dari akar dan dapat menghasilkan senyawa - senyawa yang mempercepat pertumbuhan. Biodiversitas Bakteri Rhizosfer yang terisolasi pada media Kings B dan Nutrient Agar (NA) di tanah bagian tengah, depan dan belakang lahan berjumlah 25 isolat, dengan morfologi koloni yang berbeda beda. Secara keseluruhan terdapat 22 keragaman morfologi isolat bakteri yang terisolasi pada media Kings B dan 3 isolat pada media NA. Setiap morfologi koloni yang berbeda dimungkinkan merupakan jenis yang berbeda. Jumlah populasi koloni yang terisolasi pada media Kings B bagian tengah mencapai 1,61 x $10^{8} \mathrm{cfu} / \mathrm{ml}$, bagian depan sebanyak $7,87 \times 10^{9} \mathrm{cfu} / \mathrm{ml}$ dan bagian belakang jumlah populasi tidak dapat dihitung karena setiap isolate jumlah populasinya > 250 koloni. Sedangkan yang terisolasi pada media NA untuk tanah bagian tengah dan depan jumlah koloni yang terisolasi dengan media NA tidak memenuhi syarat batas minimum dan maksimum perhitungan bakteri yang diperkenankan yaitu rentang antara $25-250$. Untuk jumlah populasi bakteri untuk tanah bagian belakang totalnya $2,23 \times 10^{3} \mathrm{cfu} / \mathrm{ml}$. Mikoriza yang ditemukan pada tegakan JUN secara keseluruhan di dominasi oleh jenis Gigaspora $(65,3 \%)$ diikuti oleh jenis Glomus $(28,6 \%)$ dan Acaulospora $(6,1 \%)$. Dua buah isolate yaitu isolate 1A dan 1B menunjukan potensi dalam menghasilkan hormone IAA pada masa inkubasi hari ke tiga. Sedangkan pada hari ke tujuh, semua isolate yang diuji dengan pereaksi Salkowsi tidak menunjukkan reaksi yang positif (warna merah tidak muncul). Pada penelitian pendahuluan ini diketahui bahwa pada hari ke tiga adalah hari optimum isolate dalam menghasilkan hormon IAA.
\end{abstract}

Kata kunci : Biodiversitas, mikroorganisme, bakteri, morfologi, hormon 


\section{PENDAHULUAN}

\section{Latar Belakang}

Indonesia terkenal dengan sebutan negara megabiodiversitas dengan keanekaragaman hayati. Namun informasi tentang biodiversitas mikroorganisme indigenos di Indonesia masih sangat minim sehingga dibutuhkan penelitian yang terus berlanjut untuk mengetahui potensi serta manfaat mikroorganisme tersebut.

Kebun percobaan Cogreg Universitas Nusa Bangsa (UNB) yang berlokasi di desa Jampang Kecamatan Parung Kabupaten Bogor selama ini belum pernah ditanami oleh tanaman jati. Sejak tahun 2007 tanaman jati varietas Unggul Nusantara yang kemudian dikenal dengan JUN telah ditanam di areal kebun percobaan Cogreg sejumlah kurang lebih 7000 pohon. Keberadaan tanaman JUN ini diduga akan merubah kondisi ekologis, sosial, dan ekonomi di lingkungan sekitarnya. Dari sudut ekologis perlu adanya suatu penelitian untuk mengetahui biodiversitas mikroorganisme. Nilai indeks biodiversitas yang didapatkan akan menentukan kualitas lingkungan akibat penanaman pohon JUN di areal perkebunan Cogreg, selain dari pada itu dapat pula digali potensi dari mikroorganisme terpilih khususnya bakteri jenis Rhizobakterium dan jamur Mikoriza sebagai fitohormon, biofertilizer, dan biodecomposer.

Tujuan dari penelitian ini adalah untuk mengetahui biodiversitas mikroorganisme penting yang berada dibawah tegakan JUN dan potensi dari mikroorganisme terpilih khususnya Rhizobakterium dan jamur Mikoriza sebagai fitohormon, biofertilizer dan biodecomposer.

\section{BAHAN DAN METODE}

Bahan yang digunakan dalam penelitian ini adalah sampel tanah di sekitar tanaman JUN, media Potato Dextrose Agar (PDA), Nutien Agar, Kings B (b.a), trytophan, tween 20, salkowski reagent (b.a), NaCl, Aquadest, kapas, kertas saring, tissue, alumunium foil, larutan sukrosa

Peralatan yang digunakan antara lain neraca analitik, $\mathrm{pH}$ meter, autoclave, oven, termometer, cawan petri, peralatan gelas, jarum ose, shaker, laminer air flow, inkubator, botol/plastik sampel, spektrofotometer visible Genesys 20, vorteks, sentrifuge, blender, satu set saringan bertingkat, pengaduk, stop watch, dan mikroskop stereo (b.a).

\section{Metode}

\section{Isolasi bakteri dari tanah sekitar tanaman jati}

Sampel tanah diambil secara komposit di tiga bagian lokasi lahan yaitu tanah bagian depan, tanah bagian belakang, dan tanah bagian tengah. Sampel tanah salah satu bagian diambil 25 gram dimasukan ke dalam erlenmayer berisi 225 $\mathrm{ml}$ aquades steril. Seri larutan dibuat sampai dengan pengenceran $10^{-10}$. Masing - masing seri pengenceran diinokulasikan ke dalam 2 cawan petri (duplo) dengan cara cawan tuang menggunakan medium Kings B dan NA. Bakteri diamati karakteristik morfologi koloninya meliputi warna, elevasi, tepi, bentuk, permukaan dan ada tidaknya lendir.

\section{Eksplorasi endomikoriza dari tanah dan akar tanaman jati}

Metode eksplorasi endomikoriza yang digunakan adalah teknik penyaringan basah (Nicholson dan Gaderman 1963). Sampel tanah atau akar sebanyak 250 gram dicampur kedalam 1 liter air dan diaduk sampai rata, kemudian dibiarkan beberapa menit sampai partikel-partikel yang besar mengendap. Saringan bertingkat disusun dari atas ke bawah beurutan mulai 60 mesh, 200 mesh dan 400 mesh. Semua bahan yang menempel pada saringan dibilas dengan air untuk menjamin tidak ada yang tertinggal di saringan. Sejumlah sisa tanah yang tertinggal pada saringan dipindahkan kedalam cawan petri dan dilihat di mikroskop dan dilakukan identifikasi. 


\section{Pembuatan stok isolat}

Bakteri yang telah diisolasi dipindahkan ke dalam agar miring yang berisi medium King $\mathrm{B}$ dan diinkubasi selama 24 jam pada suhu kamar. Kultur stok dimasukkan ke dalam kulkas.

\section{Pengukuran Jumlah Populasi dan pH Biakan Rhizobakteri}

Di dalam laminar, biakan rhizobakteri dalam medium Kings B Cair yang telah diinkubasi selama 7 hari secara aseptik dimasukkan ke dalam erlenmeyer $50 \mathrm{ml}$. Diukur jumlah populasi bakteri menggunakan spektrofotmeter pada panjang gelombang $660 \mathrm{~nm}$, serta diukur pula nilai $\mathrm{pH}$ dengan alat $\mathrm{pH}$ Meter.

\section{Analisis produksi IAA oleh Rhizobakteri}

Biakan bakteri yang ditumbuhkan dalam medium Kings B cair, pada hari ke tiga dan ke tujuh diambil $3 \mathrm{ml}$ dari erlenmeyer kemudian dimasukkan ke dalam tabung reaksi masing-masing $5 \mathrm{ml}$. Suspensi disentrifuge selama 10 menit dengan kecepatan 11.000 rpm. Kemudian sebanyak $2 \mathrm{ml}$ supernatan dimasukkan ke dalam tabung reaksi lalu ditambahkan $4 \mathrm{ml}$ pereaksi salkowski dan divorteks. Larutan dibiarkan selama 30 menit untuk pengembangan. Supernatan yang mengandung IAA akan membentuk warna merah dengan pereaksi Salkowski. Warna yang muncul diamati secara kualitatif dan dibandingkan dengan larutan standar IAA.

\section{HASIL DAN PEMBAHASAN}

\section{A. Biodiversitas Bakteri Rhizosfer}

Bakteri yang terisolasi di tanah bagian tengah lahan, mempuyai morfologi koloni yang berbeda - beda. Terdapat 3 warna koloni yaitu putih, kuning, coklat muda (krem), 3 bentuk koloni yaitu circular, irregular dan filamentous, 3 elevasi koloni mulai dari umbonate, flat dan convex dengan permukaan halus mengkilap, margin entire, labote dan filamentous, serta karakteristik optik opaque dan transparant. Secara keseluruhan terdapat 9 keragaman morfologi isolat bakteri yang terisolasi pada media Kings B. Setiap morfologi koloni yang berbeda dimungkinkan merupakan jenis yang berbeda. Jumlah populasi koloni mencapai $1,61 \times 10^{8}$ $\mathrm{cfu} / \mathrm{ml}$

Keragaman bakteri rhizosfer tanah bagian depan yang terisolasi pada media Kings B berjumlah 14 isolat. Warna koloninya adalah coklat muda dan kuning, bentuk circular dan irreguler, elevasi umbonate dan flat, permukaan halus mengkilap, margin entire dan lobate serta karakteristik optik opaque dan transparant. Jumlah populasi sebanyak $7,87 \times 10^{9}$ $\mathrm{cfu} / \mathrm{ml}$.

Bakteri rhizosfer tanah bagian belakang yang terisolasi pada media Kings B berwarna coklat muda, bentuk circular, elevasi convex, umbonate dan flat, permukaan halus mengkilap, margin entire dan lobate serta karakteristik optik opaque dan transculent. Jumlah populasi tidak dapat dihitung karena setiap isolate jumlah populasinya $>250$ koloni. Seluruh isolate yang didapat pada tanah bagian belakang dengan media Kings B berjumlah 3 isolat. Keragaman morfologi isolate bakteri rhizosfer tanah yang terisolasi pada media Kings B dapat dilihat pada Tabel 1 dan Gambar 1 dan 2.

Dengan media NA, bakteri yang terisolasi pada tanah bagian tengah, depan dan belakang terlihat pada Tabel 2 . Bakteri yang terisolasi pada tanah bagian tengah kurang beragam. Morfologi koloni terlihat terdapat 1 warna yaitu coklat muda (krem), dengan bentuk circular, elevasi convex dan umbonate, permukaan halus mengkilap, margin entire dan lobate serta karakteristik optik opaque dan transparant. Terdapat hanya 2 keragaman morfologi koloni bakteri. 
Tabel 1. Keragaman Morfologi Isolat Bakteri Rhizosfer Tanah yang Terisolasi pada Media Kings B

\begin{tabular}{|c|c|c|c|c|c|c|c|}
\hline No. & Isolat & Pigmentasi & Bentuk & Elevasi & Permukaan & Margin & $\begin{array}{c}\text { Karakteristik } \\
\text { Optik }\end{array}$ \\
\hline 1. & TK1 & Coklat muda & circular & umbonate & Halus mengkilap & entire & transparant \\
\hline 2. & TK2 & Coklat muda & circular & Flat & Halus mengkilap & entire & opaque \\
\hline 3. & TK3 & Coklat muda & circular & convex & Halus mengkilap & entire & opaque \\
\hline 4. & TK4 & Coklat muda & circular & umbonate & Halus mengkilap & lobate & opaque \\
\hline 5. & TK5 & Coklat muda & irregular & convex & Halus mengkilap & entire & opaque \\
\hline 6. & TK6 & Coklat muda & irregular & Flat & Halus mengkilap & entire & opaque \\
\hline 7. & TK7 & putih & circular & Flat & Halus mengkilap & entire & transparant \\
\hline 8. & TK8 & Coklat muda & irregular & Flat & Halus mengkilap & lobate & opaque \\
\hline 9. & TK9 & kuning & filamentous & Flat & Halus mengkilap & filament & opaque \\
\hline 10. & DK1 & Coklat muda & irregular & Flat & Halus mengkilap & lobate & opaque \\
\hline 11. & DK2 & kuning & irregular & Flat & Halus mengkilap & Lobate & Opaque \\
\hline 12. & DK3 & Coklat muda & irregular & Flat & Halus mengkilap & Entire & Opaque \\
\hline 13. & DK4 & kuning & circular & Flat & Halus mengkilap & Entire & Opaque \\
\hline 14. & DK5 & Coklat muda & irregular & Flat & Halus mengkilap & Lobate & transculent \\
\hline 15. & DK6 & Coklat muda & irregular & Flat & Halus mengkilap & Entire & Opaque \\
\hline 16. & DK7 & Coklat muda & circular & umbonate & Halus mengkilap & Lobate & Opaque \\
\hline 17. & DK8 & Coklat muda & irregular & umbonate & Halus mengkilap & Lobate & transparant \\
\hline 18. & DK9 & Coklat muda & irregular & umbonate & Halus mengkilap & Lobate & Opaque \\
\hline 19. & DK10 & kuning & irregular & umbonate & Halus mengkilap & Lobate & Opaque \\
\hline 20. & DK11 & Coklat muda & circular & umbonate & Halus mengkilap & Lobate & transculent \\
\hline 21. & DK12 & Coklat muda & irregular & umbonate & Halus mengkilap & Lobate & transculent \\
\hline 22. & DK13 & Coklat muda & circular & flat & Halus mengkilap & entire & Opaque \\
\hline 23. & DK14 & Coklat muda & circular & umbonate & kasar & entire & opaque \\
\hline 24. & BK1 & Coklat muda & circular & convex & Halus mengkilap & lobate & Opaque \\
\hline 25. & $\mathrm{BK} 2$ & Coklat muda & circular & umbonate & Halus mengkilap & Entire & Transculent \\
\hline 26. & BK3 & Coklat muda & circular & Flat & Halus mengkilap & entire & transculent \\
\hline
\end{tabular}

Keterangan :

TK = Tanah Bagian Tengah pada Media Kings B

DK = Tanah Bagian Depan pada Media Kings B

$\mathrm{BK}=$ Tanah Bagian Belakang pada Media Kings B 
Media NA ini merupakan media untuk mengisolasi bakteri secara umum namun berbeda dengan media Kings $\mathrm{B}$ yang merupakan media isolasi bakteri yang telah diperkaya unsur hara. Bila dibandingkan dengan keragaman morfologi yang terisolasi pada media Kings $\mathrm{B}$ terdapat 1 morfologi koloni bakteri yang berbeda yaitu pada isolat no.2 (Isolat TN2). Dengan demikian banyaknya keragaman morfologi koloni bakteri rhizosfer yang terisolasi pada tanah bagian tengah lahan kebun percobaan cogrek berjumlah 10 isolat. Jumlah koloni yang terisolasi dengan media NA tidak memenuhi syarat untuk dihitung karena syarat yang diperkenankan untuk dapat dihitung bila terdapat 25-250 koloni per seri pengenceran.

Bakteri yang terisolasi pada media NA di tanah bagian depan 1 terdapat 2 warna koloni yaitu putih dan coklat muda, bentuk circular dan irregular, elevasi flat dan umbonate, permukaan halus mengkilap, margin entire dan lobate serta karakteristik optik opaque. Jumlah populasi bakteri yang tumbuh pada media NA tidak dapat dihitung karena tidak memenuhi syarat batas minimum dan maksimum perhitungan bakteri yang diperkenankan yaitu rentang antara 25 250 .
Koloni yang tumbuh pada media NA terdapat 4 morfologi yang berbeda. Seluruh isolate yang didapat pada tanah bagian depan berjumlah 14 dari sampel tanah yang di isolasi pada media King's B dan 2 isolate yang berbeda ditemukan pada sampel tanah yang ditumbuhkan pada media NA (DN1 dan DN3) karena isolate DN2 sama dengan isolate DK1 dan isolate DN4 sama dengan isolate DK7 Sehingga keseluruhan dari isolate bakteri yang diperoleh sebanyak 16 isolate.

Bakteri yang terisolasi pada media NA di tanah bagian depan terdapat satu warna koloni yaitu coklat muda, bentuk circular, elevasi flat, permukaan halus mengkilap, margin entire serta karakteristik optik opaque dan transculent. Jumlah populasi bakteri yang tumbuh pada media NA yang dapat dihitung ada 4 isolat sedangkan yang masuk dalam data perhitungan yaitu isolate dari pengenceran $10^{1}$ dan $10^{2}$ yaitu totalnya $2,23 \mathrm{x}$ $10^{3} \mathrm{cfu} / \mathrm{ml}$.

Isolat yang ditemukan pada tanah bagian belakang yang tumbuh pada media NA berjumlah 2 isolate. Akan tetapi isolate $\mathrm{BN} 2$ tidak berbeda dengan isolate BK3 yang ada pada media Kings B, sehingga ada satu penambahan isolate baru dari media NA. Total seluruh isolate pada tanah bagian belakang berjumlah 4 isolat.

Tabel 2. Keragaman Morfologi Isolat Bakteri Rhizosfer Tanah yang Terisolasi pada Media NA

\begin{tabular}{cccccccc}
\hline No. & Isolat & Pigmentasi & Bentuk & Elevasi & Permukaan & Margin & $\begin{array}{c}\text { Karakteristik } \\
\text { Optik }\end{array}$ \\
\hline 1. & TN1 & Coklat muda & circular & convex & Halus mengkilap & entire & opaque \\
2. & TN2 & Coklat muda & circular & umbonate & Halus mengkilap & lobate & transparant \\
3. & DN1 & Putih & irregular & Flat & Halus mengkilap & Lobate & Opaque \\
4. & DN2 & Coklat muda & irregular & Flat & Halus mengkilap & Lobate & Opaque \\
5. & DN3 & Coklat muda & circular & Flat & Halus mengkilap & Entire & Opaque \\
6. & DN4 & Coklat muda & irregular & umbonate & Halus mengkilap & lobate & opaque \\
7. & BN1 & Coklat muda & circular & Flat & Halus mengkilap & entire & Opaque \\
8. & BN2 & Coklat muda & circular & Flat & Halus mengkilap & entire & transculent \\
\hline
\end{tabular}

Keterangan :

$\mathrm{TN}=$ Tanah Bagian Tengah Media

$\mathrm{DN}=$ Tanah Bagian Depan Media

$\mathrm{BN}=$ Tanah Bagian Belakang Media 
Tabel 3. Keragaman Morfologi Isolat Bakteri Rhizosfer Tanah di Bawah Tegakan JUN

\begin{tabular}{|c|c|c|c|c|c|c|c|}
\hline No. & Isolat & Pigmentasi & Bentuk & Elevasi & Permukaan & Margin & $\begin{array}{c}\text { Karakteristik } \\
\text { Optik }\end{array}$ \\
\hline 1. & DK1 & Coklat muda & irregular & Flat & Halus mengkilap & lobate & opaque \\
\hline 2. & DK2 & kuning & irregular & Flat & Halus mengkilap & Lobate & Opaque \\
\hline 3. & DK3 & Coklat muda & irregular & Flat & Halus mengkilap & Entire & Opaque \\
\hline 4. & DK4 & kuning & circular & Flat & Halus mengkilap & Entire & Opaque \\
\hline 5. & DK5 & Coklat muda & irregular & Flat & Halus mengkilap & Lobate & transculent \\
\hline 6. & DK6 & Coklat muda & irregular & Flat & Halus mengkilap & Entire & Opaque \\
\hline 7. & DK7 & Coklat muda & circular & umbonate & Halus mengkilap & Lobate & Opaque \\
\hline 8. & DK8 & Coklat muda & irregular & umbonate & Halus mengkilap & Lobate & transparant \\
\hline 9. & DK9 & Coklat muda & irregular & umbonate & Halus mengkilap & Lobate & Opaque \\
\hline 10. & DK10 & kuning & irregular & umbonate & Halus mengkilap & Lobate & Opaque \\
\hline 11. & DK11 & Coklat muda & circular & umbonate & Halus mengkilap & Lobate & transculent \\
\hline 12. & DK12 & Coklat muda & irregular & umbonate & Halus mengkilap & Lobate & transculent \\
\hline 13. & DK13 & Coklat muda & Circular & Flat & Halus mengkilap & Entire & Opaque \\
\hline 14. & DK14 & Coklat muda & Circular & Umbonate & Kasar & Entire & Opaque \\
\hline 15. & DN1 & Putih & Irregular & Flat & Halus mengkilap & Lobate & Opaque \\
\hline 16. & DN3 & Coklat muda & Circular & Flat & Halus mengkilap & Entire & Opaque \\
\hline 17. & TK1 & Coklat muda & Circular & Umbonate & Halus mengkilap & Entire & Transparent \\
\hline 18. & TK3 & Coklat muda & Circular & Convex & Halus mengkilap & Entire & Opaque \\
\hline 19. & TK5 & Coklat muda & Irreguler & Convex & Halus mengkilap & Entire & Opaque \\
\hline 20. & TK7 & Putih & Circular & Flat & Halus mengkilap & Entire & Transparant \\
\hline 21. & TK9 & Kuning & Filamen & Flat & Halus mengkilap & Filamento & Opaque \\
\hline 22. & TN2 & Coklat muda & tous & Umbonate & Halus mengkilap & us & Transparent \\
\hline 23. & BK1 & Coklat muda & Circular & Convex & Halus mengkilap & Lobate & Opaque \\
\hline 24. & BK2 & Coklat muda & Circular & Umbonate & Halus mengkilap & Lobate & Transculent \\
\hline 25. & $\mathrm{BK} 3$ & Coklat muda & $\begin{array}{l}\text { Circular } \\
\text { Circular }\end{array}$ & Flat & Halus mengkilap & $\begin{array}{l}\text { Entire } \\
\text { Entire }\end{array}$ & Transculent \\
\hline
\end{tabular}

Keterangan :

DK = Tanah Bagian Depan Media Kings B

DN = Tanah Bagian Depan Media NA

TK = Tanah Bagian Tengah Media Kings B

$\mathrm{TN}=$ Tanah Bagian Tengah Media NA

$\mathrm{BK}=$ Tanah Bagian Belakang Media Kings B

\section{B. Biodiversitas Mikoriza Arbuskular}

\section{Isolasi Cendawan Mikoriza}

Arbuskular (CMA) dilakukan dengan Teknik Penyaringan Basah Tanah dalam 250 gram tanah bagian tengah, ditemukan 3 jenis mikoriza yang didominasi Mikoriza Gigaspora (66,7\%), diikuti Glomus (25\%) dan Acaulospora (8,3\%). Pada tanah bagian depan ditemukan 2 jenis mikoriza dengan jumlah didominasi Mikoriza Gigaspora (83,3\%), diikuti Glomus (16,7\%) sedangkan untuk jenis Acaulospora tidak ditemukan. Pada tanah bagian belakang ditemukan 3 jenis mikoriza dengan didominasi Mikoriza Gigaspora (56,0\%), diikuti Glomus $(36,0 \%)$ dan Acaulospora (8,0\%).

Dari ketiga bagian wilayah lahan (tengah, depan dan belakang) terlihat bahwa Gigaspora mendominasi semua bagian tanah/lahan, dikuti Glomus dan Acaulospora. Mikoriza paling banyak didapat pada bagian belakang ( 25 spora), diikuti bagian tengah dan depan dengan jumlah yang sama (12 spora). Tanah pada bagian depan ditemukan lebih sedikit jenis mikoriza (2 jenis) dibandingkan tanah bagian tengah dan belakang dengan jumlah jenis masing-masing 3 jenis.

Bila dibandingkan dengan hasil penelitian Sugiarti (2009) jumlah mikoriza yang ditemukan di kebun percobaan Cogrek meningkat baik dari jenis maupun jumlah spora yang ditemukan. Pada penelitian Sugiarti (2009) hanya ditemukan 2 jenis mikoriza yaitu Gigaspora dan Glomus dari daerah perakaran tanaman tumpangsari disela - sela tegakan JUN yang berumur 2 tahun, sedangkan pada 
rhizosfer tanaman jati tidak ditemukan spora mikoriza. Bahkan tanah rizosfer yang diteliti juga telah dilakukan trapping (perbanyakan) terlebih dahulu pada tanaman shorgum selama 3 bulan. Pada penelitian ini tanah langsung diteliti tanpa dilakukan trapping (perbanyakan) terlebih dahulu pada tanaman inang. Hal ini membuktikan bahwa ekologi kebun percobaan cogrek telah mengalami perubahan yang positif dengan adanya penanaman JUN, salah satu indikatornya adalah dengan ditemukannya spora mikoriza yang lebih banyak baik jenis maupun jumlahnya. Faktor lain yang diduga mempengaruhi hasil penelitian ini adalah waktu pengambilan sampel yang merupakan musim penghujan, sehingga kondisi lingkungan mendukung mikoriza untuk tumbuh dan berkembang biak.

Mikoriza yang ditemukan pada daerah rizosfer tanaman JUN saat ini diduga berasal dari mikoriza tanaman tumpangsari disela - sela tegakan JUN umur 2 tahun yang kemudian bermigrasi ke tanaman JUN. Dugaan sangat dimungkinkan karena jenis mikoriza yang ditemukan di tanaman JUN ini sama dengan jenis mikoriza yang ditemukan di tanaman tumpangsari dibawah tegakan JUN umur 2 tahun di kebun percobaan Cogrek hasil penelitian Sugiarti, 2009. Selain itu juga ada mikoriza yang memang kehadirannya baru belakangan ada yaitu jenis Acaulospora.

Mikoriza yang ditemukan pada tegakan JUN secara keseluruhan di dominasi oleh jenis Gigaspora $(65,3 \%)$ diikuti oleh jenis Glomus $(28,6 \%)$ dan Acaulospora $(6,1 \%)$.

\section{Potensi Rhizobakter Sebagai Penghasil Hormon IAA}

Potensi Rhizobakter sebagai penghasil hormon IAA dilakukan secara kualitatif dan kuantitatif. Sejumlah isolate Rhizobakter telah diidentifikasi awal dalam menghasilkan hormon IAA. Isolate dibiakan dalam medium cair Kings B yang mengandung protease pepton, gliserol, $\mathrm{K}_{2} \mathrm{HPO}_{4}, \mathrm{MgSO}_{4}$, dan L- Triptophan. Isolate diinkubasi selama 7 hari sambil dishaker, setelah itu diuji dengan pereaksi Salkowski ditunjukkan pada Gambar 3. Jika memberikan warna merah berarti isolat memiliki potensi dalam menghasilkan hormon IAA.

Dua buah isolat yaitu isolat $1 \mathrm{~A}$ dan 1B menunjukan potensi dalam menghasilkan hormone IAA pada masa inkubasi hari ke 3. Hasil uji IAA isolate tersebut ditunjukkan pada Gambar 4. Sedangkan pada hari ke tujuh, semua isolate yang diuji dengan pereaksi Salkowsi tidak menunjukkan reaksi yang positif (warna merah tidak muncul). Pada penelitian pendahuluan ini diketahui bahwa pada hari ke tiga adalah hari optimum isolate dalam menghasilkan hormone IAA. Untuk Selanjutnya akan dilakukan penelitian mengenai waktu inkubasi dan $\mathrm{pH}$ medium optimum bagi isolate dalam menghasilkan IAA.

Tabel 4. Jenis dan Populasi Mikoriza pada Tanah Tegakan JUN

\begin{tabular}{ccccc}
\hline No & Lokasi & \multicolumn{3}{c}{ Jenis } \\
\cline { 3 - 5 } & & Gigaspora & Glomus & Acaulospora \\
\hline 1 & Tengah & 8 & 3 & 1 \\
2 & Depan & 10 & 2 & - \\
3 & Belakang & 14 & 9 & 2 \\
\hline & & & $14(28,6 \%)$ & $3(6,1 \%)$ \\
\hline
\end{tabular}


Tabel 5. Pengamatan Biakan Bakteri dalam Medium Kings B setelah diinkubasi Selama 7 Hari

\begin{tabular}{|c|c|c|c|}
\hline Isolate & $\mathrm{pH}$ & $\begin{array}{c}\text { Nilai OD } \\
\text { (Optical Density)* }\end{array}$ & Pengamatan IAA secara kualitatif \\
\hline DK13 & 7,49 & 1,211 & Semua isolate pada hari ke 7 tidak \\
\hline DK14 & 8,50 & 0,659 & memberikan reaksi positif terhadap pereaksi \\
\hline DN1 & 7,62 & 1,076 & Salkowski \\
\hline DN3 & 8,76 & 0,246 & \\
\hline TK1 & 8,40 & 1,324 & \\
\hline TK3 & 8,69 & 0,875 & \\
\hline TK5 & 8,80 & 0,676 & \\
\hline TK7 & 8,73 & 0,780 & \\
\hline TK9 & 8,62 & 0,677 & \\
\hline TN2 & 8,55 & 1,067 & \\
\hline
\end{tabular}

* Nilai OD diukur dengan mengguanakan

Spektrofotometer Visible Genesis 20 pada $\lambda 660 \mathrm{~nm}$

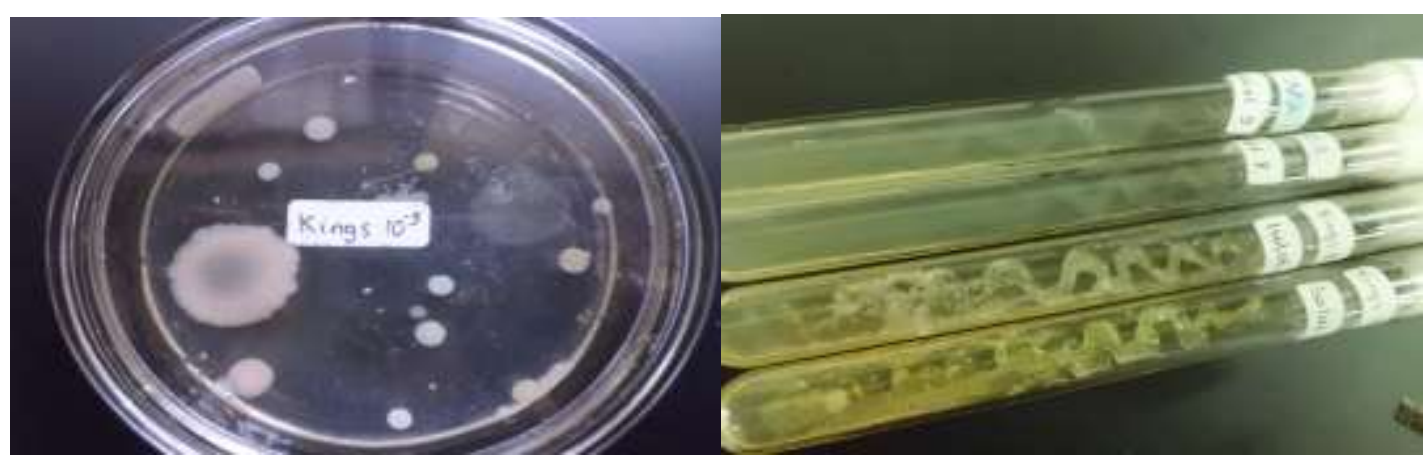

Gambar 1. Hasil Isolasi Bakteri Rizosfer pada media Kings B

Gambar 2. Hasil Isolasi Agar Miring
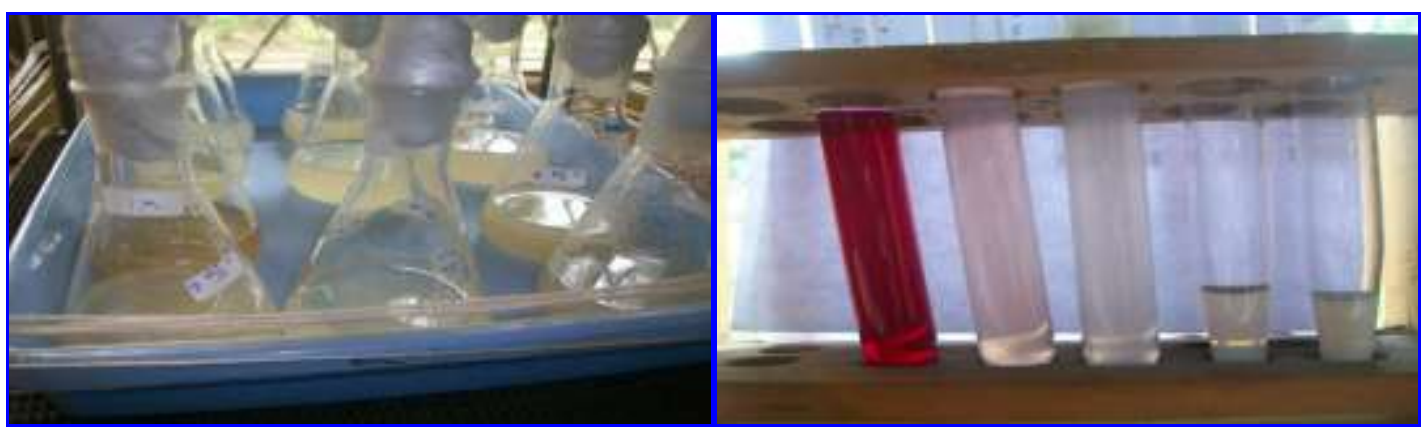

Gambar 3. Kultur Rhizobakteri pada media Gambar 4. Hasil Uji Potensi Hormon IAA Cair King's B cair umur 2 hari Inkubasi hari ke 3

\section{KESIMPULAN}

Biodiversitas mikroorganisme dibawah tegakan JUN beragam dengan ditemukankan 25 ragam isolate bakteri dan
3 jenis mikoriza yaitu Gigaspora, Glomus dan Acaulospora. Beberapa isolate bakteri telah menunjukkan potensi dengan menghasilkan hormone IAA. 


\section{DAFTAR PUSTAKA}

Atmaja, I W. D., 2001. Bioteknologi Tanah (Ringkasan Kuliah). Jurusan Tanah Fakultas Pertanian Universitas Udayana. Denpasar.

Chalimah, S., Muhadiono, A. Latifah, H. Said dan M. N. Toruan, 2007. Perbanyakan Gigaspora sp dan Acaulospora sp dengan Kultur Pot di Rumah Kaca, Biodiversitas ISSN: 1412-033X Volume 7. Nomor 4 Halaman: 12-19, Bogor.

Hakim, N., M. Y. Nyakpa, A. M. Lubis, S. G. Nugroho, M. R. Saul, M. A. Diha, Go Ban Hong dan H.H. Bailey, 1986. Dasar - dasar Ilmu Tanah. Universitas Lampung. Lampung

Husna, T. F. D dan Mahfudz, 2007. Aplikasi Mikoriza Untuk Memacu Pertumbuhan Jati di Muna. Info Teknis Vol 5 No 1. Balai Besar Penelitian Bioteknologi Dan Pemuliaan Tanaman Hutan.

Iskandar, D., 2002. Pupuk Hayati Mikoriza Untuk Pertumbuhan dan Adapsi Tanaman Di Lahan Marginal.

Maslahat, M. dan Suharyanto, 2005. Analisis Indol Acetic Acid (IAA) dari Mikroorganisme yang di Isolasi dari Tanaman Karet (Hevea brasiliensis). Jurnal Nusa Kimia Vol. 5 No. 2. Hal. 26 - 35.

Pujiyanto, 2001. Pemanfatan Jasad Mikro, Jamur Mikoriza dan Bakteri Dalam Sistem Pertanian Berkelanjutan Di Indonesia: Tinjauan Dari Perspektif Falsafah Sains. Makalah Falsafah Sains
Program Pasca Sarjana Institut Pertanian Bogor. Bogor.

Rahayu, N. dan A. K. Akbar, 2003. Pemanfaatan Mikoriza dan Bahan Organik Dalam Rangka Reklamasi Lahan Pasca Penambangan. Karya Tulis Ilmiah. Fakultas Pertanian Universitas Tanjungpura. Pontianak.

Santosa, D. A, 1989. Teknik dan Metode Penelitian Mikorisa VesikularArbuskular. Laboratorium Biologi Tanah Jurusan Tanah Fakultas Pertanian Institut Pertanian Bogor. Bogor.

Subiksa, IGM, 2002. Pemanfatan Mikoriza Untuk Penanggulangan Lahan Kritis. Makalah Falsafah Sains Program Pasca Sarjana Institut Pertanian Bogor. Bogor.

Sugiarti, L., 2009. Inventarisasi Cendawan Mikoriza Arbuskula (CMA) pada Tanaman Tumpang Sari Di Antara Tegakan Jati Unggul Nusantara (JUN) di Kebun Percobaan Cogrek, Bogor. Jurnal Nusa Tani Vol. 9 No. 1 Hal. 49 - 55.

Suharyanto dan M. Maslahat, 2007. Pengaruh Penambahan Tripton Sebagai Prekusor Primer Dalam Medium Pertumbuhan Rhizobium sp. Terhadap Produksi IAA. Jurnal Nusa Kimia. Vol. 7 No. 1. Hal. 23-32.

Suwardji, 2003. Profil Wilayah Lahan Kering Propinsi NTB: Potensi, Tantangan dan strategi Pengembangannya. Makalah Seminar Nasional FOKUSHIMITI $B E W$ III di Mataram. Universitas Mataram. Mataram. 